\title{
SEED DORMANCY OF HYBRIDS AND PARENT LINES OF SUNFLOWER (Helianthus annuus L.)
}

\author{
Vujaković, M. ${ }^{{ }^{*}}$, Radić, V. ${ }^{2}$, Miklič, V. ${ }^{2}$, Jovičić, D. ${ }^{2}$, \\ Balešević-Tubić, S. ${ }^{2}$, Mrđa, J. ${ }^{2}$, Škorić, D. ${ }^{3}$
}

${ }^{1}$ Agricultural Extension Service "Agricultural Station", Novi Sad, Serbia

${ }^{2}$ Institute of Field and Vegetable Crops, Novi Sad, Serbia

${ }^{3}$ Serbian Academy of Sciences and Arts (SASA), Branch in Novi Sad, Serbia

Received: November 15, 2011 Accepted: June 10, 2012

\section{SUMMARY}

Sunflower is a plant species with a prominent period of seed dormancy. Physiological maturation period can be accelerated under laboratory conditions using methods for breaking seed dormancy such as: previous cooling at $5-10^{\circ} \mathrm{C}$, previous heating at $30-35^{\circ} \mathrm{C}$, gibberellic acid treatment, $\mathrm{KNO}_{3}$, ethrel, etc. The aim of this study was to determine the duration of seed dormancy period of different sunflower hybrids and parent lines produced in Serbia, and to determine which of the methods for breaking seed dormancy gives the best results. Studies were carried out on five commercial sunflower hybrids and their parental components. Seed germination was determined after harvesting using standard laboratory methods and tetrazolium tests. The following methods were used for seed dormancy breaking: low temperature treatment of 5$10^{\circ} \mathrm{C}$, high temperature treatment of $30-35^{\circ} \mathrm{C}$, and treatment with gibberellic acid. The tests were performed in the period of 30,50 , and 90 days after harvesting.

The application of gibberellic acid method gave the lowest values of seed germination, while statistical significant differences between the control and method of low and high temperatures were not found. Sunflower hybrids Sremac, Duško, NS-H-111, Velja and Branko, as well as the female lines of hybrid NS-H-111, and male lines of hybrids Sremac and Velja had no prominent seed dormancy 30 days after harvesting. Seed dormancy in female lines of hybrids Sremac, Duško, Velja and Branko and male lines of hybrids Duško, NS-H-111 and Branko was decreased 90 days after storage, but it was not completely removed.

Key words: sunflower, seed dormancy, seed germination

* Corresponding author: Phone: 021/478-02-20; Fax: 021/6412-180;

e-mail:milka.vujakovic@gmail.com 


\section{INTRODUCTION}

Sunflower is the plant species primarily grown in Serbia for the production of edible oil, and it is used as a high protein and honey-bearing plant (to a certain extent). Sunflower is grown on some 23 billion hectares in more than 40 countries in the world (Seiler et al., 2008), and in our country in the last four years the area under sunflower ranged between 130.000 and 150.000 ha. Due to the areas on which it is grown and large areal extent it is necessary to produce high quality seed able to germinate immediately after the harvest.

Sunflower is the plant species with a prominent seed dormancy period. Seed dormancy is defined as the property of the seed that prevents its germination even under favorable environmental conditions. Seed shows pronounced primary dormancy after harvesting, while the secondary dormancy can occur due to unfavorable environmental factors. Mechanism of dormancy in sunflower seed is not well known. According to Kucera et al. (2005) the possible cause of seed dormancy is accumulation of abscisic acid during seed ripening. The thickness and permeability of seed coat, as well as differences between genotypes, may also be the cause of seed dormancy (Subramanyam et al., 2002). Environmental factors during seed ripening period may increase or reduce the seed dormancy period. Many authors believe that besides water and the length of photoperiod, the temperature is a very important environmental factor that affects the seed dormancy (Schuurink et al., 1992). It was beleived that dormancy and germination were temperature regulated, and seed germination only light regulated. However, new studies revealed significant influence of light on seed dormancy as well (Baskin and Baskin, 2004).

Sunflower seed can germinate 10-12 days after pollination, when its germinability is only $2.25 \%$, and 40 days after pollination its germinability can be as high as $58.25 \%$ (Ahmed et al., 2002). The same author studied duration of seed dormancy an determined that seed germination 5 days after harvest was $58.25 \%$, and after 75 days it was $97.75 \%$. Radić (2006) determined that seed of female component in sunflower hybrid could germinate a week after pollination, while the same period is somewhat longer in restorer lines. The same author then stated that germination of the seed of parental components of sunflower hybrids after 6 weeks was above $85 \%$. Miklič (2001), on the other hand, stated that the ability of sunflower seed to germinate during maturation could be achieved prior to its physiological maturation. Germinability can reach the value of $93 \%$ at the moment when a germ is 10-12 days old, but decline later due to the onset of dormancy, accumulation of growth inhibitors, and hull hardening. The period of physiological maturation under laboratory conditions can be accelerated using some of the methods for dormancy breaking, such as previous cooling at the temperature of $5-10^{\circ} \mathrm{C}$, previous heating at the temperature of $30-35^{\circ} \mathrm{C}$, application of gibberellic acid (ISTA, 2010). Maiti et al. (2006a) used boiling water, ethrel, aceton $\left(\mathrm{CH}_{3} \mathrm{COCH}_{3}\right)$ and potassium nitrate $\left(\mathrm{KNO}_{3}\right)$ for dormancy breaking in sunflower seed. 
The aim of this paper was to determine the dormancy period of seed belonging to different sunflower hybrids, and their parental lines produced in Serbia, and to determine which of the breaking dormancy methods give the best results.

\section{MATERIAL AND METHOD}

This study included five commercial sunflower hybrids and their parental components selected at the Institute of Field and Vegetable Crops in Novi Sad. Seed desiccation was done prior to harvest, and the harvest was done between September $15^{\text {th }}$ and $30^{\text {th }}$.

Seed germination was tested after harvesting under laboratory conditions in the Laboratory for Seed Testing of the Institute of Field and Vegetable Crops in Novi Sad.

Testing seed germination was carried out on four replicates of 100 seeds by applied Standard laboratory test (ISTA, 2010) and tetrazolium test (ISTA, 2003).

Prior to application of the Standard laboratory test the seed was submitted to the following methods for dormancy breaking: previous cooling at $5-10^{\circ} \mathrm{C}$ for 7 days $(\mathrm{Ph})$; previous heating at $30-35^{\circ} \mathrm{C}$ for 7 days $(\mathrm{Pg})$; application of $0.05 \%$ gibberellic acid concentration $\left(\mathrm{GA}_{3}\right)$.

After the above mentioned treatments the seed was germinated at $25^{\circ} \mathrm{C}$ during 10 days period. Germination values obtained by seed germination under optimal laboratory conditions with no applied method for seed dormancy breaking were used as control (C).

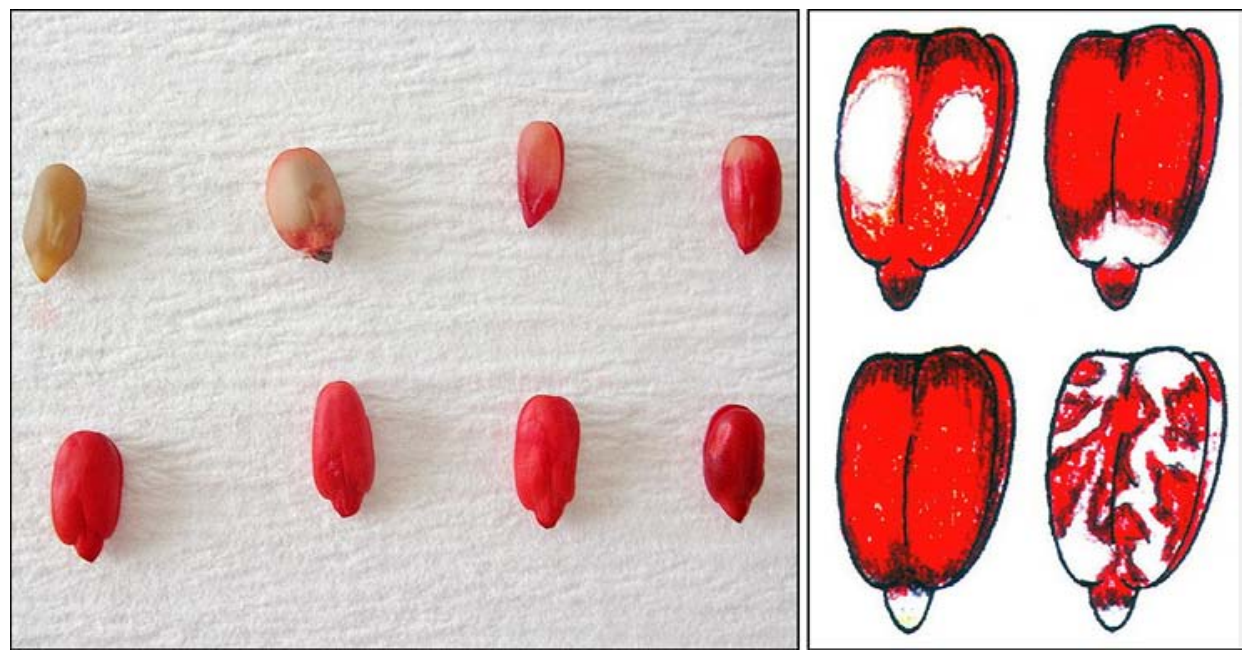

Figure 1: Tetrazolium test applied on sunflower seed (left) and schematic representation of several possibilities of sunflower seed dyeing (right) (ISTA, 2003)

Tetrazolium test (TT) was applied on $4 \times 100$ seed. The seed was first submerged into water for $17 \mathrm{~h}$, and after that hulled and placed in a $1 \%$ tetrazolium 
solution. After $4 \mathrm{~h}$ the percentage of viable seeds was determined. All tissues (necessary for normal seedling development) of a viable seed needed to be dyed. Apart from completely dyed, viable seeds, and completely undyed, unviable seeds, a partly dyed seeds may also be found. Depending on the species, small undyed spots of some parts of these tissues may be accepted. Location, size of undyed areas, and sometimes intensity of dyeing determine whether some seed is considered as viable or not (Figure 1).

Seed germination was determined 30 days after harvest. In variants where there was no difference between seed germination obtained by applied tetrazolium test, and other tests the germination was not repeated. In variants where there were differences, germination of seed kept at $18^{\circ} \mathrm{C}$ was repeated 60 and 90 days after harvest. Seed germination was obtained by applied control variant and low temperature treatment.

Obtained results were statistically analyzed by applying analysis of variance and correlation analysis using the MSTAT program.

\section{RESULTS AND DISCUSSION}

Tetrazolium test was developed in 1950 as a test for obtaining rapid and general estimation of seed viability, particularly in species with expressed dormancy, since germination test would last too long (Hampton and TeKrony, 1995). Seed germination ranged from 76 to $98 \%$ when Tetrazolium test was applied (Table 1).

Table 1: Germination of sunflower seed obtained by application of different methods for dormancy breaking

\begin{tabular}{|c|c|c|c|c|c|c|c|c|c|c|c|c|c|c|c|c|}
\hline & \multicolumn{16}{|c|}{ Genotypes } \\
\hline Test & 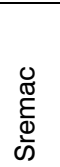 & 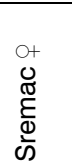 & 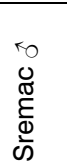 & 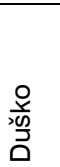 & 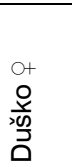 & $\begin{array}{l}\text { ro } \\
0 \\
\frac{\partial}{x \omega} \\
\frac{10}{0}\end{array}$ & $\begin{array}{l}\frac{T}{T} \\
\frac{1}{1} \\
\text { D) }\end{array}$ & $\begin{array}{l}\text { O+ } \\
\mp \\
\frac{T}{T} \\
\frac{T}{\dot{1}} \\
\text { D }\end{array}$ & 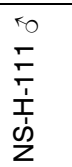 & $\frac{\frac{\sigma}{\sigma}}{>}$ & $\frac{\text { O+ }}{\frac{\pi}{0}}$ & $\begin{array}{l}\frac{\pi}{\pi} \\
\frac{\pi}{\pi}\end{array}$ & $\begin{array}{l}\frac{\rho}{\frac{\nu}{\mathbb{T}}} \\
\frac{\pi}{\bar{m}}\end{array}$ & $\begin{array}{l}\text { O+ } \\
\text { ᄋ } \\
\frac{\text { L }}{\mathbb{N}} \\
\frac{\pi}{\omega}\end{array}$ & 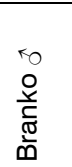 & 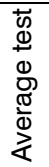 \\
\hline TT & 93 & 77 & 91 & 93 & 83 & 96 & 91 & 91 & 89 & 95 & 76 & 91 & 95 & 88 & 98 & 90 \\
\hline C & 87 & $56^{*}$ & $86^{*}$ & 91 & $59^{\star}$ & $84^{*}$ & 88 & 92 & $65^{*}$ & 95 & $65^{\star}$ & 92 & 95 & $61^{*}$ & $88^{*}$ & 80 \\
\hline $\mathrm{Ph}$ & 88 & $58^{*}$ & 89 & 92 & $47^{\star}$ & $86^{*}$ & 91 & 87 & $65^{\star}$ & 94 & $64^{*}$ & 92 & 96 & $67^{\star}$ & $90 *$ & 80 \\
\hline $\mathrm{Pg}$ & 92 & $66^{\star}$ & 88 & 92 & $56^{\star}$ & $81 *$ & 91 & 92 & $68^{*}$ & 93 & $66^{*}$ & 87 & 93 & $68^{*}$ & $87^{*}$ & 81 \\
\hline $\mathrm{GA}_{3}$ & 92 & $67^{*}$ & 88 & $86^{*}$ & $61^{*}$ & $79^{*}$ & $84^{*}$ & 88 & $62^{*}$ & 93 & $62^{*}$ & $84^{*}$ & 92 & $62^{*}$ & $77^{*}$ & 78 \\
\hline
\end{tabular}

When tetrazolium is applied the viable germ parts are stained and potential seed germination is obtained. Its application is used not to determine the percentage of normal and abnormal seedlings, due to which higher germination values are obtained, which is considered a defect of Tetrazolium test. Since potential germinability of seed is obtained by this test, the results of all applied tests were compared 
to the values obtained by Tetrazolium test, which represents maximum seed germination. Based on the values obtained by applied tetrazolium tests it was observed that female components of hybrids Sremac $(77 \%)$ and Velja (76\%) did not satisfy the minimum value for seed germination prescribed by the Rule on quality of seed of agricultural plants (Sl list 47/87), which is $80 \%$. Seed of female line of hybrid Duško had potential germiability of $83 \%$, which was lower than the value prescribed in most of European countries, where minimum value is $85 \%$.

Statistically significant highest values of seed germination were obtained for applied tetrazolium test by comparison of average value for applied tests, and statistically significant lowest values for applied gibberellic acid. Values for seed germination obtained for control (70\%) were at the same statisticall level as the values obtained by application of low temperature $(80 \%)$ and high temperature $(81 \%)$.

Higher values of seed germination were obtained for hybrids in relation to parental lines. In studied hybrids there were no statistically significant differences between values obtained by tetrazolium test and those obtained by application of some other methods for dormancy breaking, which revealed that in these hybrids produced in 2010, dormancy was not expressed 30 days after harvest. Maiti et al. (2006b) studied presence of dormancy in 59 sunflower genotypes and concluded that 16 of them had no expressed dormancy.

Statistically significant higher values with applied tetrazolium test, in relation to other applied tests, were obtained for female lines of hybrid Sremac, Duško, Velja, Branko and male lines of hybrids Duško, NS-H-111 and Branko. Strong positive relationship among all applied tests was determined by applied correlation analysis (Table 2).

Table 2: Correlation coefficient for sunflower seed germination obtained by applied tests

\begin{tabular}{lcccc}
\hline Test & $\mathrm{C}$ & $\mathrm{Ph}$ & $\mathrm{Pg}$ & $\mathrm{GA}_{3}$ \\
\hline $\mathrm{TT}$ & 0.712 & 0.732 & 0.692 & 0.544 \\
$\mathrm{C}$ & - & 0.907 & 0.887 & 0.853 \\
$\mathrm{Ph}$ & - & - & 0.892 & 0.788 \\
$\mathrm{Pg}$ & - & - & - & 0.825 \\
\hline
\end{tabular}

Germination of seed 60 days after harvest obtained by applied low temperature and control in female line of hybrids Sremac, Duško, Velja and Branko and male line of hybrids Duško, NS-H-111 and Branko was statistically significantly lower compared to the values obtained by application of tetrazolium test (Table 3). Germination of seed 90 days after harvest obtained by application of low temperature treatment in female line of hybrid Duško and male line of hybrids Duško and Branko was statistically significantly lower compared to the values obtained by application of tetrazolium tests. Since values were above $80 \%$ further studies were not continued.

Seed dormancy in studied hybrids was not expressed 30 days after harvest, while in some lines it was expressed even after 90 days. One of the possible causes 
of such expressed dormancy were the conditions of production. That is, female lines of hubrids Sremac, Duško, Velja and Branko and male lines of hibryd Duško were produced at the location where there was approx. $100 \mathrm{~mm}$ more rainfall compared to the locality where female lines of hybrid NS-H-111, and male lines of hybrids NS-H-111, Sremac, Velja and Branko were produced. The influence of locality on seed germination was determined by Miklič et al. (2009). Radić et al. (2009) claimed that seed production should be organized at several different locations in order to obtain high quality seed. Another possible reason for the absence of seed germination is coat permeability and the seed properties and further studies should be carried out in that direction. Maiti et al. (2006b) claimed that the seed produced under drought conditions had harder coat, and more compact nucleus compared to seed produced under conditions with more moisture, and that such structure diminished the possibility of water intake, which was reflected in germination itself.

Table 3: Germination of some sunflower lines 30, 60 and 90 days after harvest

\begin{tabular}{|c|c|c|c|c|c|c|c|c|}
\hline \multirow[b]{2}{*}{ Test } & \multicolumn{8}{|c|}{ Genotypes } \\
\hline & Sremac ㅇ & Duško q & Duško $\widehat{\partial}$ & NS-H-111 & Velja 우 & Branko $q$ & Branko $\widehat{\jmath}$ & $\begin{array}{c}\text { Average } \\
\text { test }\end{array}$ \\
\hline TT & 77 & 83 & 96 & 89 & 76 & 88 & 98 & 87 \\
\hline $\mathrm{Ph}-30 \mathrm{~d}$ & $58^{*}$ & $47^{*}$ & $86^{\star}$ & $65^{\star}$ & $64^{*}$ & $67^{*}$ & $90 *$ & 68 \\
\hline C-30 d & $56^{*}$ & $59 *$ & $84^{*}$ & $65^{\star}$ & $65^{\star}$ & $61 *$ & $88 *$ & 68 \\
\hline $\mathrm{Ph}-60 \mathrm{~d}$ & $65^{\star}$ & $60 *$ & $90 *$ & $67^{*}$ & $67^{\star}$ & $71^{*}$ & $86^{*}$ & 72 \\
\hline C-60 d & $58^{*}$ & $52^{*}$ & $82^{*}$ & $70 *$ & $65^{\star}$ & $54^{*}$ & $85^{*}$ & 67 \\
\hline Ph-90 d & 80 & $77^{*}$ & $83^{*}$ & 88 & 80 & 84 & $87^{*}$ & 83 \\
\hline C-90 d & 77 & $73^{*}$ & $82^{\star}$ & 85 & 76 & $78^{*}$ & $87^{*}$ & 80 \\
\hline
\end{tabular}

\section{CONCLUSION}

Based on obtained results the following conclusions can be made:

The lowest germination values were obtained by applied gibberellic acid for dormancy breaking.

Statistically significant differences were not found between control and method of low and high temperatures.

Sunflower hybrids Sremac, Duško, NS-H-111, Velja and Branko and female lines of hybrid NS-H-111 and male lines of hybrids Sremac and Velja had no expressed seed dormancy 30 days after harvest.

Seed dormancy of female lines of hybrids Sremac, Duško, Velja and Branko and male lines of hybrids Duško, NS-H-111 and Branko was decreased 90 days after harvest, but it was not completely removed. Sowing of these lines immediately 
after harvest would make the achievement of optimal stand impossible, which could also be reflected in the seed yield. Further research should be devoted to studying composition and structure of seed coat and nucleus, the possible causes of sunflower seed dormancy.

\section{ACKNOWLENDGEMENT}

This research is part of the project 31025: Development of new varieties and production technology improvement of oil crops for different purposes, sponsored by the Ministry of Education and Science, Republic of Serbia.

\section{REFERENCES}

Ahmed, S., Cheema, N.M., Khan, I.A., Rana, M.A.. 2002. Effect of age of developing kernel on germination and dormancy in sunflower. Pakistan J. Agric. Res. 17(1): 67-70.

Baskin, C.C., Baskin, J.M., 2004. Determining dormancy - breaking and germination requirements from the fewest seeds. Strategies for Survival, Island Press, Washington. Pp. 162179.

Hampton, J.G., TeKrony, D.M., 1995. Handbook of Vigour Test Methods, $3^{\text {rd }}$ Edition, International Seed Testing Association.

ISTA, 2010. International Rules for Seed Testing. International Seed Testing Association, Switzerland.

ISTA, 2003. Working sheets on tetrazolium testing Agricultural, Vegetables and Horticultural Species. Vol. I, International Seed Testing Association, Switzerland.

Kucera, B., Cohn, M.A., Leubner-Metzger, G., 2005. Plant hormone interactions seed dormancy release and germination. Seed Science Research 15: 281-307.

Maiti, R.K., Vidyasagar, P., Shahapur, S.C., Ghosh, S.K., Seiler, G.J., 2006a. Development and standardization of a simple technique for breaking seed dormancy in sunflower (Helianthus annuus L.). Helia 29(45): 117-126.

Maiti, R.K., Vidyasagar, P., Shahapur, S.C., Seiler, G.J., 2006b. Studies on genotypic variability and seed dormancy in sunflower genotypes (Helianthus annuus L.). Indian J. Crop Science 1 (1-2): 84-87.

Miklič, V., 2001. Uticaj momenta desikacije na semenski kvalitet i prinos suncokreta. Doktorska disertacija. Univerzitet u Novom Sadu, Poljoprivredni fakultet.

Miklič, V., Balalić, I., Jocić, S., Marinković, R., Hladni, N., Gvozdenović, S., Stojšin, V., 2009. Produktivnost NS hibrida suncokreta u multilokacijskim ogledima i preporuka sortimenta za 2009. godinu. Zbornik radova Instituta za ratarstvo i povrtarstvo 46: 293-310.

Radić, V., 2006. Effect of maturation period on seed quality; optimum time for desiccation in sunflower (Helianthus annuus L.) genotypes. Helia 29(44): 145-153.

Radić, V., Vujaković, M., Marjanović-Jeromela, A., Mrđa, J., Miklič, V., Dušanić, N., Balalić, I., 2009. Interdependence of sunflower seed quality parameters. Helia 32(50): 157-164.

Schuurink, R.C., van Beckum, M.M., Heidekamp, F., 1992. Modulation of grain dormancy in barley by variation of plant growth conditions. Hereditas 177: 137-143.

Seiler, G.J., Jan, C., Gulya, T.J., 2008. Use of wild Helianthus species in sunflower breeding. In: Proceedings of the International Conference on conventional and molecular breeding of field and vegetable crops, November 24-27, 2008, Novi Sad, Serbia. Pp. 71-76.

Subrahmanyam, S.V.R., Kumar, S.S., Ranganatha, A.R.G., 2002. Genotypic differences for seed dormancy in sunflower (Helianthus annuus L.). Seed Res. 30: 325-327. 
